\title{
Least limiting water range under no-tillage system and maize grain yield
}

\section{Intervalo hídrico ótimo em sistema plantio direto e rendimento de grãos de milho}

\author{
Claudia KLEIN ${ }^{1,2}$; Vilson Antonio KLEIN ${ }^{3}$ \\ 1 Parte da dissertação de mestrado do primeiro autor \\ 2 Engenheira Agrônoma Mestre, Doutoranda do Programa de Pós Graduação em Agronomia da Universidade de Passo \\ Fundo, Bolsista Fapergs; klein811@hotmail.com \\ ${ }^{3}$ Autor para correspondência; Engenheiro Agrônomo, Doutor, Professor da Universidade de Passo Fundo, Laboratório \\ de Física e Água do Solo; BR 285, São José | Passo Fundo/RS | CEP: 99052-900; vaklein@upf.br
}

Recebido em: 05-09-2014; Aceito em: 25-11-2014

\begin{abstract}
The water content range where plants take water from the soil without any restriction is called the least limiting water range (LLWR). The adequate soil water availability of is intimating linked to the development and growth of plants. Soil management that promotes greater water storage and water availability in soil has been widely studied and published to enable higher productivity. The aim of the present study was to determine the LLWR of a Hapludox under no-tillage, the chiseling effect on the property, and relate it to the soil water content variation of the field and the influence on grain yield. The following parameters were measured: bulk density, LLWR, soil water retention, variation of water storage, and biometric parameters of maize and maize grain yield. Concluded that the LLWR and the number of days the soil water content remained within the LLWR was higher under no-tillage chiseled, and greater maize grain yield.
\end{abstract}

Additional keywords: chiseling; soil water content.

\begin{abstract}
Resumo
A faixa de umidade em que as plantas retiram água do solo em condições menos limitantes é denominada de "intervalo hídrico ótimo" (IHO). A adequada disponibilidade de água no solo está intimamente ligada ao desenvolvimento e crescimento das plantas. Manejos do solo que promovem maior armazenamento e disponibilidade de água às plantas vêm sendo amplamente estudados e divulgados, a fim de possibilitarem maior rendimento. Este estudo teve como objetivos avaliar o intervalo hídrico ótimo (IHO) de um Latossolo Vermelho distrófico húmico, manejado com sistema plantio direto; o efeito da escarificação neste indicador, bem como avaliar o comportamento da umidade do solo e a influência desta sobre o rendimento de grãos de milho. As variáveis analisadas foram: densidade do solo, retenção de água no solo, volubilidade da armazenagem de água, intervalo hídrico ótimo e parâmetros biométricos da cultura do milho (massa de espiga, de grãos e de ráquis) e rendimento de grãos. Concluiu-se que o $\mathrm{IHO}$ e o número de dias em que 0 teor de água no solo permaneceu dentro da faixa do IHO foi maior no manejo plantio direto escarificado, o que incrementou o rendimento de grãos de milho.
\end{abstract}

Palavras-chave adicionais: água no solo; escarificação.

\section{Introduction}

Agriculture faces serious problems of availability of water resources. Soil is the water reservoir for plants, being extremely important to the use of managements that provide greater infiltration, storage, redistribution of water in the soil and availability to plants.

In areas managed with no-tillage, the superficial compaction of the soil, due to the traffic of machines and no soil disturbance (Tavares Filho et al., 2001) have been causing problems in soil structure, such as increased density, reduction in porosity, limiting infiltration and redistribution of water, affecting plant growth and may result in reduced yields (Modolo et al., 2008).
The advantages of mechanical soil chiseling have been inferred by many research papers. It proves to be an efficient technique of decompression, improves the physical properties of the soil and in some cases increases crop yields (Secco et al., 2009) and in others not (Pauletti et al. 2003; Debiasi et al., 2010). Conflicting results with regard to grain yield can be attributed to the degree of soil compaction before the intervention, the prevailing weather conditions during the crop cycle, the type and adjustments of the disk harrow used, the operation depth of the plowing mechanism used during sowing and the performance or not of secondary tillage (harrowing). In most papers no description about these items is presented. 
This practice reduces soil resistance to root penetration (Veiga et al., 2007), the soil bulk density (Klein \& Camara, 2007), increases the total porosity (Silva Junior et al., 2010), hydraulic conductivity of the soil and infiltration (Camara \& Klein, 2005). The pore distribution is changed, generally by increasing the proportion of macropores (Klein et al., 2008) and reduction of less than $0.0002 \mathrm{~mm}$ pores and volume increase of pores that retain water and provide it to the plants.

The least limiting water range (LLWR) is the range of water content in soil defined by the upper limit of the water content of the soil at field capacity condition, or the water content in the soil resulting in an air-filled porosity of $10 \%$, and the lower limit by the water content in the permanent wilting point, or the water content in which the soil resistance to penetration reaches an assumed limiting value (Kay et al., 1997).

The growth conditions of plants within the LLWR boundaries are less limiting (Silva \& Kay, 1997), so the narrower the LLWR, the greater the difficulty of managing water management (Jawayardane \& Chan, 1994).

Studies show that the correlation between the LLWR and yield of wheat and maize grains are weak (Benjamin et al., 2003), indicating the influence of other limiting factors. Gubiani et al. (2012) state that the modeling of the dynamics of the physical factors should include weather and plant conditions, which determine the soil water extraction rate and the dynamics of water, mechanical and aeration stress. On the other hand, Silva \& Kay (1996) observed a reasonable correlation between the number of days when the soil moisture condition was out of the LLWR range and the maize growth, but Klein \& Camara (2007) have not found a relation between this parameter and the yield of soybeans.

This study aimed to evaluate the effect of chiseling on the LLWR, the number of days the water content remains within the boundaries of the LLWR and the yield of maize grains.

\section{Material and methods}

The experiment was carried out in Passo Fundo/RS, with an average altitude of $680 \mathrm{~m}$ and rainy subtropical climate. The soil is classified as Hapludox, the average particle size composition of $0.49 \mathrm{~kg} \mathrm{~kg}^{-1}$ of clay, $0.13 \mathrm{~kg} \mathrm{~kg}^{-1}$ of silt and $0.38 \mathrm{~kg} \mathrm{~kg}^{-1}$ of sand.

The experiment consisted of two soil managements, being them no-tillage (NT) and no-tillage chiseled (CNT) in plots of $45 \mathrm{~m}^{2}$ and eight repetitions. The area was being managed in no-tillage since 1999, with crop rotation, maize and soybeans in the summer, black oat, wheat and barley in winter. It was verified that the relative density of the soil was greater than 0.90 , indicating compression, the chiseling was performed in May 2010, after soybean harvest, using a disk harrow with five stems of parabolic shape, spaced $35 \mathrm{~cm}$ apart, tip width of $1.87 \mathrm{~cm}$ at the end and $7.82 \mathrm{~cm}$ in the middle, cutting disk with a diameter of $43.2 \mathrm{~cm}$ and roller in an average working depth of $25 \mathrm{~cm}$. It was not performed any secondary tillage and black oat was sown immediately after chiseling in order to provide soil cover.

One year after the chiseling, soil samples were collected in the interrow with preserved structure using stainless steel cylinders with $5 \mathrm{~cm}$ hight and $5 \mathrm{~cm}$ internal diameter $\left( \pm 100 \mathrm{~cm}^{3}\right.$ ) (two management vs. seven layers $0-5,5-10,10-15,15-$ $20,20-30,30-40$ and $40-50 \mathrm{~cm}$ with eight repetitions) with the aid of an Uhland type sampler, for the determination of soil bulk density (BD), field capacity $(\mathrm{FC})$, soil resistance to penetration (RP). In this experimental arrangement, the layers were assumed as split plots.

The water content at field capacity condition was determined by subjecting the samples to the tension of $0.006 \mathrm{MPa}(6 \mathrm{kPa})$ in porous plate funnels and the permanent wilting point (PWP) was estimated by the model of Klein et al. (2010), in which PWP $\left(\mathrm{g} \mathrm{g}^{-1}\right)=0.0003$ clay $\left(\mathrm{g} \mathrm{kg}^{-1}\right)+0.0118 \quad\left(\mathrm{R}^{2}=0.91\right)$, being the clay content obtained by the pipette method (EMBRAPA, 1997).

The soil mechanical resistance to penetration (RP) was obtained in penetrometer, equipped with a $200 \mathrm{~N}$ load cell rod and stem with cone of $4 \mathrm{~mm}$ base diameter and half top angle of $30^{\circ}$, receiver interface attached to a microcomputer for data collection through its own product software. The Busscher's equation (Busscher, 1990) was adjusted to the RP values into account the soil bulk density and water content in the soil.

The LLWR was determined for each soil management, according to the methodology described by Silva et al. (1994). The attributes calculated were: the minimum air-filled porosity (AFP) of $0.10 \mathrm{~m}^{3} \mathrm{~m}^{-3}$ by subtracting $0.10 \mathrm{~m}^{3} \mathrm{~m}^{-3}$ from total porosity (Sojka, 1992); water content in the soil at permanent wilting point (PWP) in the tension of $1500 \mathrm{kPa}$; water content in the soil at field capacity $(\mathrm{FC})$ in the tension of $6 \mathrm{kPa}$; water content in the soil for each density in which it reaches the resistance to penetration (RP) of $2 \mathrm{MPa}$ (Taylor et al., 1966; Nesmith, 1987) or $3 \mathrm{MPa}$, due to the evidence that this value can be the most appropriate for maize crop.

The tension of $6 \mathrm{kPa}(0,006 \mathrm{MPa})$ was used as a condition of field capacity due to Vieira \& Klein (2007) have determined for the same soil and managements, this tension by the instantaneous profile method, in which the drain was significantly reduced 2 to 3 days after the flood of the plot.

Sowing of $\mathrm{P} 1630 \mathrm{H}$ hybrid maize was performed on October 1st, 2010, using a no-tillage fertilizer seeder, with a machete type plowing for deposition of manure operating at $10 \mathrm{~cm}$ deep, in the line spacing of $0.9 \mathrm{~m}$. 
From bolting to the maize harvest (1/7/2011 to $02 / 18 / 2011$ ), the monitoring of the water in the soil was performed, because this period is considered the most critical and decisive for grain production (Aldrich et al, 1982). Deformed samples were collected every two days, with the aid of an screw auger in the 0-5, 5$10,10-15,15-20,20-30,30-40$ and $40-50 \mathrm{~cm}$ layers, and for determining the water content, they were dried at $\pm 105^{\circ} \mathrm{C}$ to constant weight, which, with the density of the soil corresponding to each depth, were converted into water content based on volume.

Maize ears were harvested in the central $6 \mathrm{~m}$ of the rows of plants of each of 16 plots, the number of rows and the number of grains per line were counted, and after threshed, the grain mass and the mass of the ears were determined; the mass of thousand grains and the moisture were adjusted to $13 \%$.
The managements were subjected to analysis of variance. In the cases where the $F$ test was significant, means were compared by Tukey test at $5 \%$ error probability.

\section{Results and discussions}

The soil bulk density (Table 1), one year after the chiseling was lower in no-tillage chiseled (CNT) in layer 5 to $15 \mathrm{~cm}$, not differing from the rest of no-tillage (NT), being these the layers where the compression is more intense in the NT system, demonstrating the effectiveness of chiseling, as a mechanical practice, to minimize this limiting factor to the development and productivity of plants, as well as its lasting effect when performed together with vegetative practices, such as the use of cover crops to soil cover.

Table 1 - Soil bulk density (BD) due to management of no-tillage (NT) and no-tillage chiseled (CNT) and sampled soil layer.

\begin{tabular}{|c|c|c|c|c|c|}
\hline \multirow{3}{*}{$\begin{array}{c}\text { Layer } \\
(\mathrm{cm})\end{array}$} & \multicolumn{4}{|c|}{ Management } & \multirow{2}{*}{ Mean } \\
\hline & \multicolumn{2}{|c|}{ NT } & \multicolumn{2}{|c|}{ CNT } & \\
\hline & \multicolumn{2}{|c|}{ 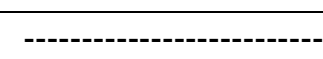 } & \multicolumn{2}{|c|}{ (Mg m$\left.{ }^{-3}\right)$} & - n---- \\
\hline $0-5$ & $A$ & $1.21 \mathrm{~cd}$ & A & $1.19 \mathrm{~cd}$ & 1.20 \\
\hline $5-10$ & $A$ & $1.33 a b$ & $B$ & $1.22 \mathrm{~cd}$ & 1.27 \\
\hline $10-15$ & A & $1.34 a b$ & B & $1.26 a b c$ & 1.30 \\
\hline $15-20$ & A & $1.31 \mathrm{ab}$ & A & $1.30 \mathrm{ab}$ & 1.30 \\
\hline $20-30$ & A & $1.35 a$ & A & $1.32 \mathrm{a}$ & 1.33 \\
\hline $30-40$ & A & $1.27 \mathrm{Bc}$ & A & $1.23 \mathrm{bcd}$ & 1.25 \\
\hline $40-50$ & A & $1.18 d$ & A & $1.17 d$ & 1.18 \\
\hline Mean & \multicolumn{2}{|c|}{1.28} & \multicolumn{2}{|c|}{1.24} & - \\
\hline C.V. (\%) & \multicolumn{2}{|c|}{ Management $=8.68$} & \multicolumn{2}{|c|}{ Layer $=4.86$} & - \\
\hline
\end{tabular}

The LLWR (Figure 1) shows that in the NT the resistance to root penetration (RP) $(2 \mathrm{MPa})$ became limiting from the $\mathrm{BD}$ of $1.05 \mathrm{Mg} \mathrm{m}^{-3}$ while in $\mathrm{RP}(3 \mathrm{MPa})$ it was $1.20 \mathrm{Mg} \mathrm{m}^{-3}$. In the CNT the density values in which RP was higher than the PWP were $1.15 \mathrm{Mg} \mathrm{m}^{-3}$ and $1.25 \mathrm{Mg} \mathrm{m}^{-3}$ for 2 and $3 \mathrm{MPa}$ of $\mathrm{RP}$ respectively. In both managements to $\mathrm{RP}(2 \mathrm{MPa})$ data of critical $\mathrm{BD}$ were extrapolated, considering that the minimum BD (Table 1) are greater, but this estimate demonstrates the behavior of phenomenon that is consistent with the results obtained in the RP (3 $\mathrm{MPa})$, which are real, considering the densities obtained in the study.

The upper limit of the LLWR (UL) was restricted by moisture in FC, and the lower limit (LL) at low BD by PWP and then by the RP, agreeing with Tormena et al. (1999), who state that in most analyzed soils, RP (2 MPa) is the LL of the LLWR, being it considered the determining factor for plant growth.

The LLWR (UL - LL) in CNT in the lower BD $\left(1.17 \mathrm{Mg} \mathrm{m}^{-3}\right)$ was $0.18 \mathrm{~m}^{3} \mathrm{~m}^{-3}$ and in the higher $\mathrm{BD}$ $\left(1.32 \mathrm{Mg} \mathrm{m}^{-3}\right), 0.09 \mathrm{~m}^{3} \mathrm{~m}^{-3}$ and in NT it was $0.16 \mathrm{~m}^{3} \mathrm{~m}^{-3}$ and $0.06 \mathrm{~m}^{3} \mathrm{~m}^{-3}$ for the lower and higher $\mathrm{BD}$ respectively. In terms of water depth available to the plants, with minimal constraints, this represents an increase of 10 and $15 \mathrm{~mm}$ for the lower and higher $\mathrm{BD}$, in the CNT compared to NT.

The critical density (CBD) (Silva et al. 1997), as that in which the LLWR is zero, i.e., the lower limit (LL) crosses the UP, in the PR (2 MPa) the CBD was $1.46 \mathrm{Mg} \mathrm{m}^{-3}$ (NT and CNT), and in the RP (3 MPa) $1.53 \mathrm{Mg} \mathrm{m}^{-3}$ (CNT) and $1.54 \mathrm{Mg} \mathrm{m}^{-3}(\mathrm{NT})$, beyond these CBD highly restrictive conditions to the crop development occurs (Table 2 and Figure 2). 


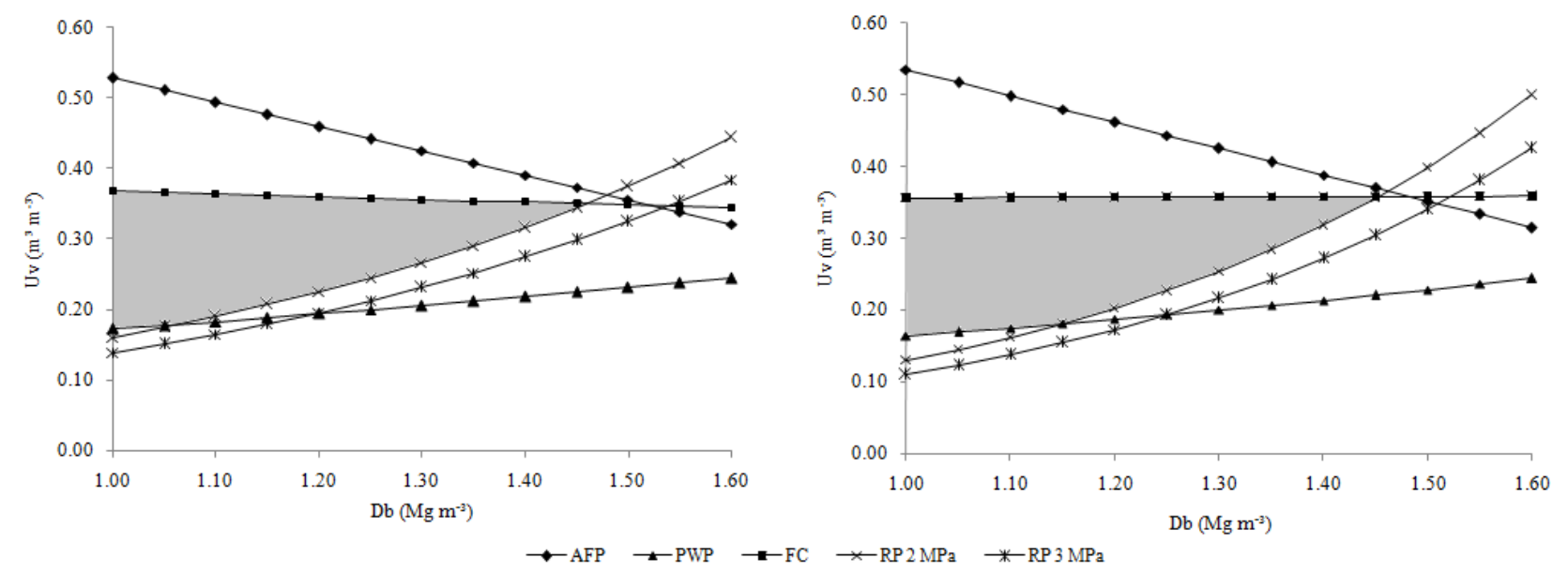

Figure 1 - Water content due to soil bulk density (BD) to the critical levels of $6 \mathrm{kPa}$ (water content to $6 \mathrm{kPa}$ (FC)), air-filled porosity (AFP) to $0.1 \mathrm{~m}^{3} \mathrm{~m}^{-3}$, permanent wilting point (PWP) to $1,500 \mathrm{kPa}$ and soil mechanical resistance to penetration (RP) of $2.0 \mathrm{MPa}$ or $3 \mathrm{MPa}$, based on the management of no-tillage (NT) and notillage chiseled (CNT).

Table 2 - Critical soil bulk density (CBD) for the resistance to penetration (RP) $2 \mathrm{MPa}$, RP $3 \mathrm{MPa}$, air-filled porosity (AFP), and least limiting water range (LLWR) = O to RP $2 \mathrm{MPa}$ or $3 \mathrm{MPa}$ due to the management of no-tillage (NT) and no-tillage chiseled (CNT) cropping systems.

\begin{tabular}{|c|c|c|c|c|c|}
\hline \multirow{2}{*}{ Management } & $\mathrm{RP} 2 \mathrm{MPa}$ & $\mathrm{RP} 3 \mathrm{MPa}$ & AFP & $\begin{array}{l}\text { LLWR=0 } \\
\text { RP } 2 \mathrm{MPa}\end{array}$ & $\begin{array}{l}\text { LLWR=0 } \\
\text { RP } 3 \mathrm{MPa}\end{array}$ \\
\hline & ------ & & $\partial(M g n$ & & ------ \\
\hline NT & 1.05 & 1.20 & 1.52 & 1.46 & 1.54 \\
\hline CNT & 1.15 & 1.25 & 1.47 & 1.46 & 1.53 \\
\hline
\end{tabular}
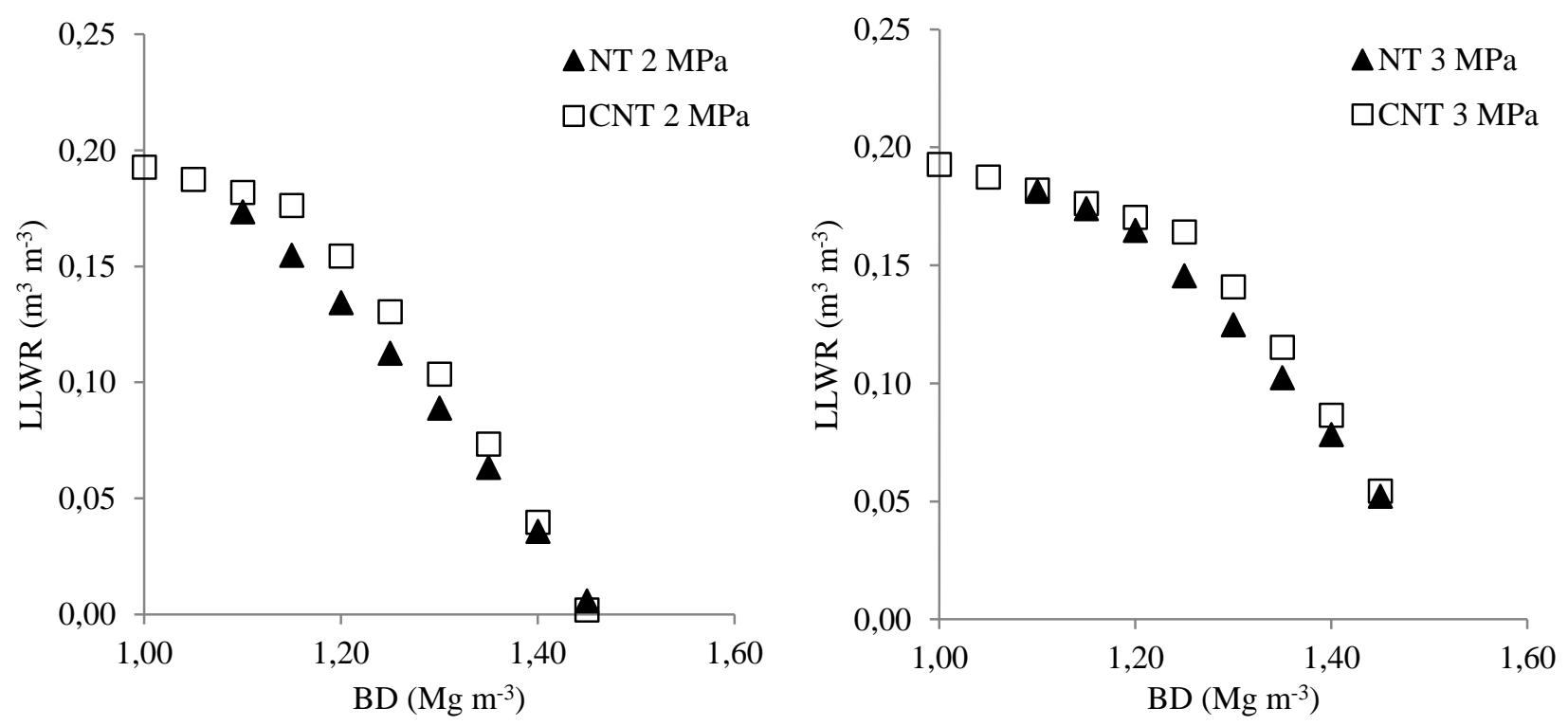

Figure 2 - Least limiting water range (LLWR) according to the bulk density (BD) for two limiting scenarios (2 or $3 \mathrm{MPa}$ ) of resistance to penetration.

The CBD values for the two managements were similar, since it is an inherent soil property related to the texture and density of the solids. Klein \& Camara (2007) also report similarity in the BD values and attribute this characteristic to the soil, regardless of the adopted management.

The behavior of the LLWR in layers, this was lower in NT (Figure 3). There has been a decrease in the layers $10-15$ and $20-30 \mathrm{~cm}$ in NT and $20-30 \mathrm{~cm}$ in CNT. In CNT little variation in UL (FC) in depth was 
observed, this result is justified by the determination of the FC in the laboratory, if it was determined by instantaneous profile, the variation would possibly be greater, although Vieira \& Klein (2007) have obtained good relation between the $\mathrm{FC}$ in the field and the water content to $6 \mathrm{kPa}$. The highest LLWR in both managements was obtained in the $0-5$ and $40-50 \mathrm{~cm}$ layers.

The LLWR for RP (3 MPa), was the same in both managements in layers $30-40$ and $40-50 \mathrm{~cm}$, being $0.14 \mathrm{~m}^{3} \mathrm{~m}^{-3}$ and $0.17 \mathrm{~m}^{3} \mathrm{~m}^{-3}$, respectively, in the other layers, the LLWR was higher in the CNT. The lowest LLWR in the NT has occurred in layers 10-15 and $20-30 \mathrm{~cm}\left(0.10 \mathrm{~m}^{3} \mathrm{~m}^{-3}\right)$, and the highest in the CNT has occurred in the layer $20-30 \mathrm{~cm}, 0.13 \mathrm{~m}^{3} \mathrm{~m}^{-3}$. It must be observed that these values refer to the entire layer, considering that the center of the layer was used as a reference for the graphic interpolation of data.

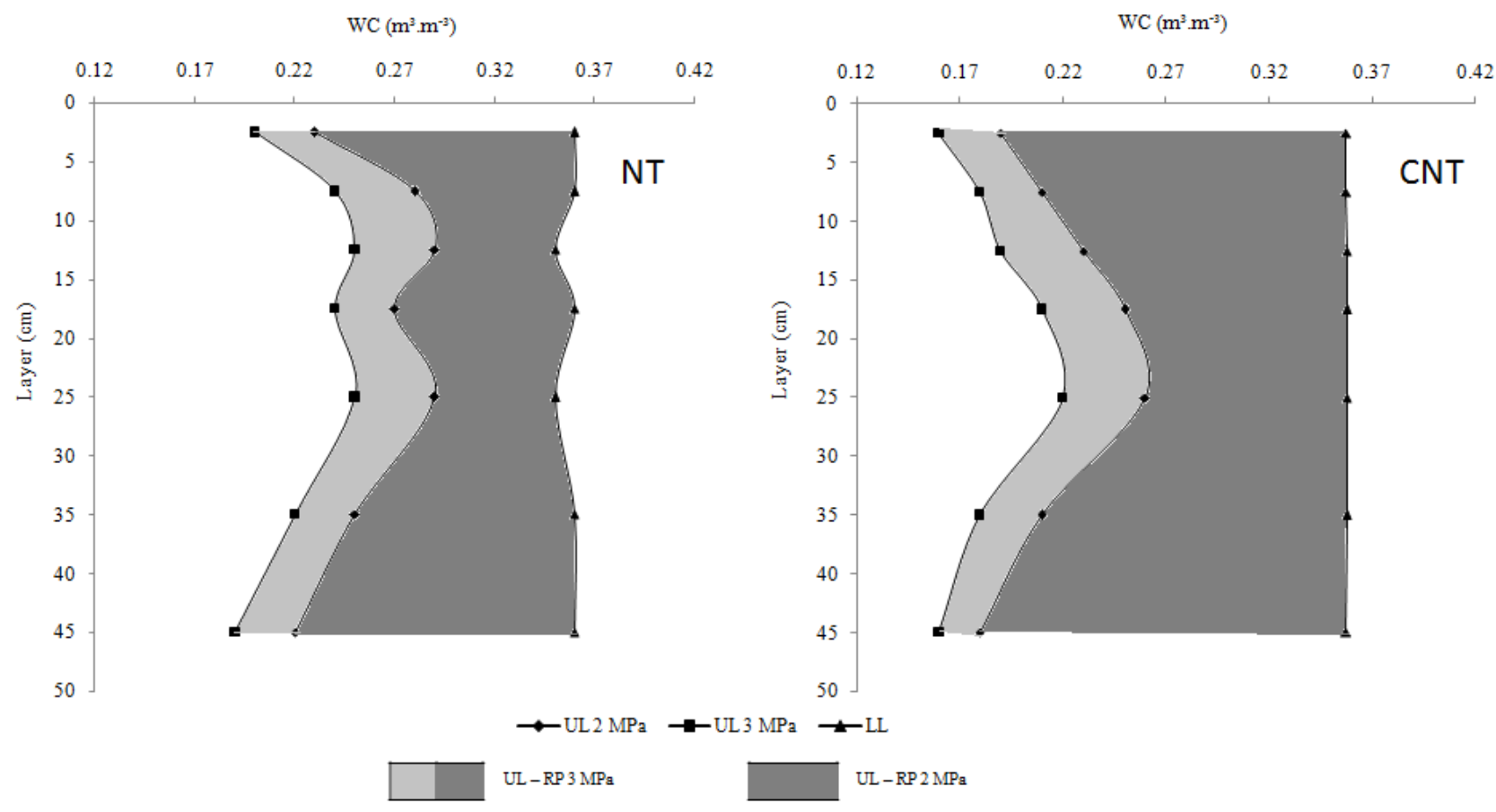

Figure 3 - Least limiting water range in the management of no-tillage (NT) and no-tillage chiseled (CNT) according to the sampled soil layer, upper limit (UL): water content (WC) to $6 \mathrm{kPa}$, lower limit (LL): resistance to penetration 2 or $3 \mathrm{MPa}$.

The water content of the soil in the field was associated with the UL of the LLWR (FC) and the LL (PR $2 \mathrm{MPa}$ and $3 \mathrm{MPa}$ ) and are shown on Figures 4 and 5. In NT, there were no limitations on the UL in any of the layers, i.e., there was no aeration deficiency in this soil (Figure 4). When the LL RP $3 \mathrm{MPa}$ is used, the LLWR increases, decreasing therefore the critical periods; when the LL RP $2 \mathrm{MPa}$ is used, this range becomes narrower, increasing limitations on the growth and development of plants. It must be stressed that the limits used are offered by studies (Taylor \& Gardner, 1963; Tavares Filho et al. 2001), are references to discussions and to legitimize the phenomenon, and that depending on environmental conditions, they do not affect root growth (Klein \& Camara, 2007).

In CNT in layers $30-40$ and $40-50 \mathrm{~cm}$, the index indicates that there have been no limitations. The water content of the soil was maintained during the entire period within the LLWR (Figure 5). Since the water content in the $20-30 \mathrm{~cm}$ layer remained most of the time within the LLWR, considering the LL RP $3 \mathrm{MPa}$, when the RP $2 \mathrm{MPa}$ the LLWR is reduced. Considering the LL RP $3 \mathrm{MPa}$ in the CNT, the layers $0-10$ and $10-20 \mathrm{~cm}$ had few critical periods of water in the soil, compared with NT.

Considering only the LL RP $3 \mathrm{MPa}$, it can be clearly seen that the CNT (Figure 5) remained within the LLWR for a longer period than NT (Figure 4), demonstrating once again the advantage of chiseling in soils under NT.

Table 3 shows the days when the water content of the soil was out of the restriction limits proposed by the LLWR. In LL RP (3 MPa) the analyzed profile for NT remained out of the LLWR for 11 days and in LL RP (2 MPa) for 19 days $(10-20 \mathrm{~cm}$ ), whereas in the CNT this restriction was lower, the RP ( $3 \mathrm{MPa}$ ) remained for only 3 days out of the LLWR and the RP (2 MPa) for 12 days $(20-30 \mathrm{~cm})$, indicating that during assessed period the conditions in NT were more restrictive to the plant development. 


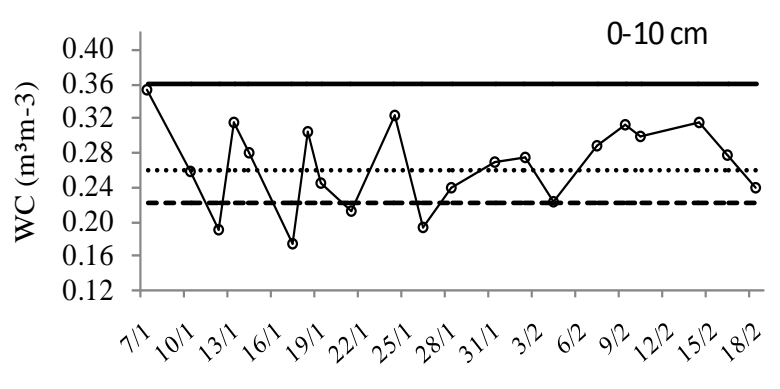

Date

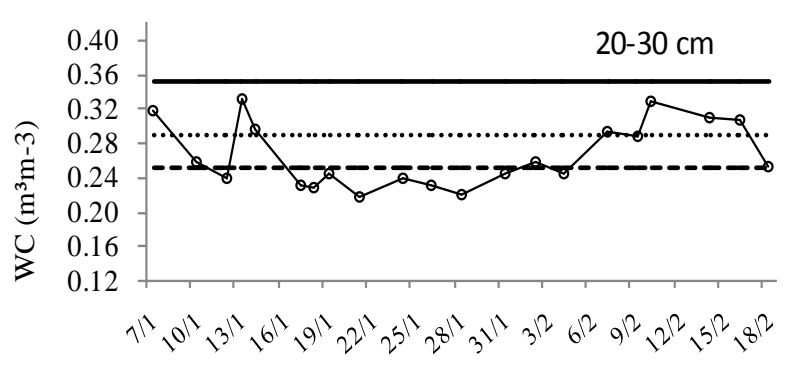

Date
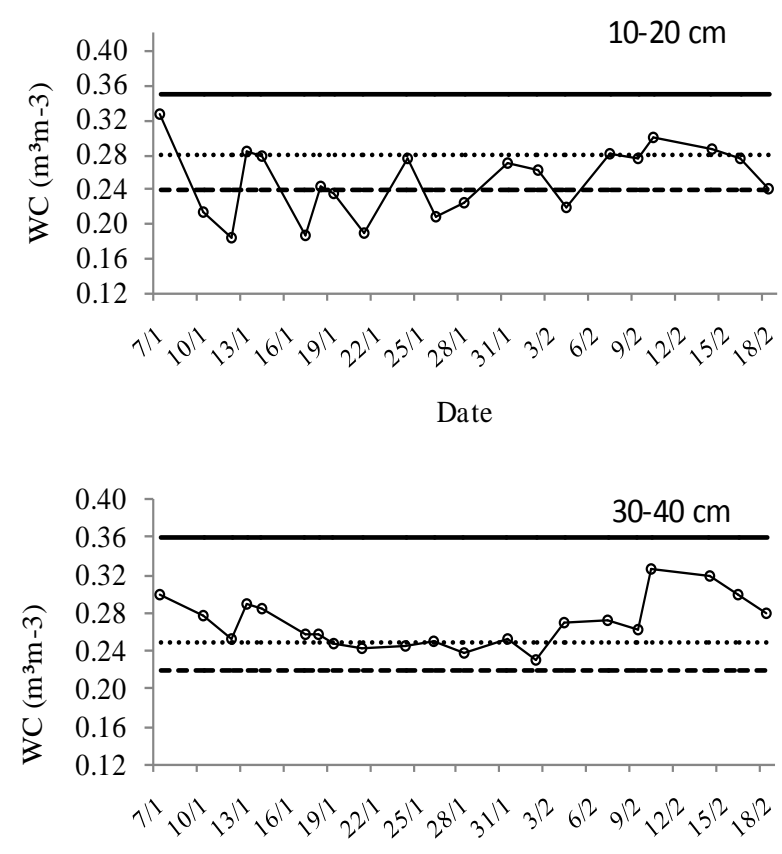

Date

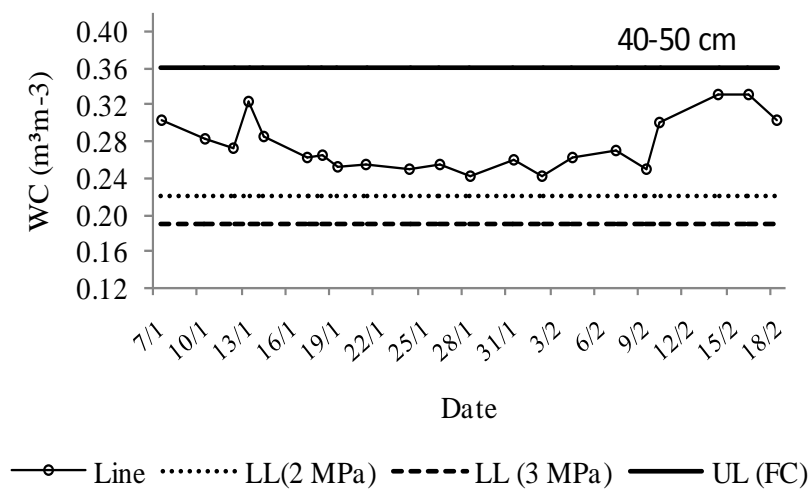

Figure 4 - Water content (WC; $\mathrm{m}^{3} \mathrm{~m}^{-3}$ ) of least limiting water range (LLWR) of the soil in the management with no-tillage (NT) from January 7th, 2011 to February 18th, 2011 according to the sampled soil layer, being the upper limit (UL): water content to $6 \mathrm{kPa}$; lower limit (LL): resistance to penetration 2 or $3 \mathrm{MPa}$

Table 3 - Number of days* in which the water content in the field remained out of the boundaries of least limiting water range according to the managements of no-tillage (NT) and no-tillage chiseled (CNT) considering the upper limit of water content to $6 \mathrm{kPa}$, and lower limits, resistance to penetration of 2 or $3 \mathrm{MPa}$.

\begin{tabular}{ccrcccc}
\hline & & \multicolumn{5}{c}{ Soil layer $(\mathrm{cm})$} \\
\cline { 3 - 6 } Management & Lower limits & $0-10$ & $10-20$ & $20-30$ & $30-40$ & $40-50$ \\
\cline { 3 - 6 } & & 5 & 11 & 10 & 0 & 0 \\
\hline NT & RP 3 MPa & 2 & 1 & 3 & 0 & 0 \\
CNT & RP 3 MPa & 10 & 19 & 18 & 13 & 0 \\
NT & RP 2 MPa & 10 & 5 & 12 & 0 & 0 \\
CNT & RP 2 MPa & 3 & &
\end{tabular}

${ }^{*}$ Based on 44 days of collected data. 


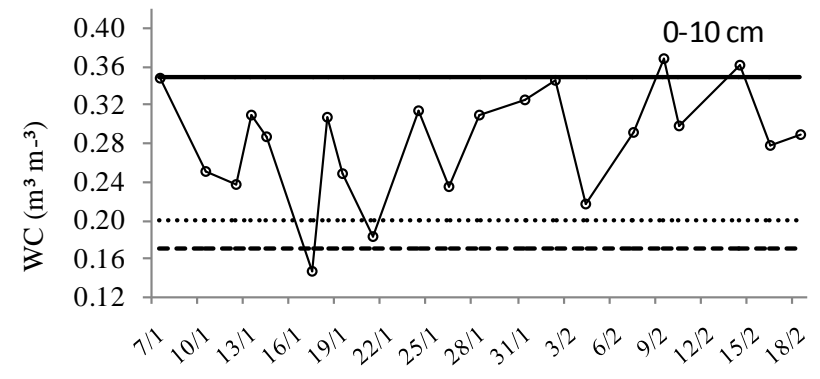

Date

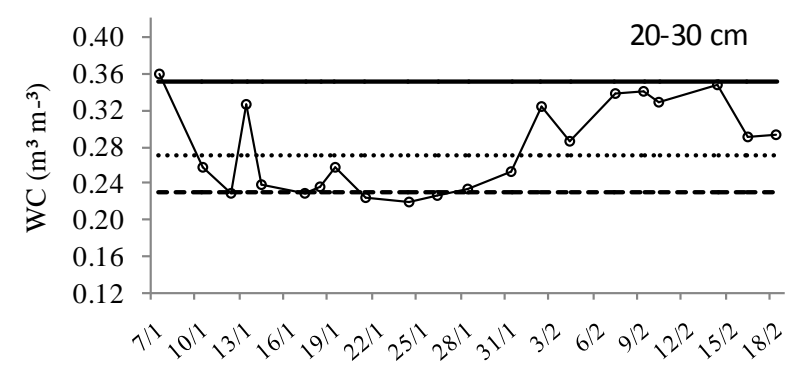

Date

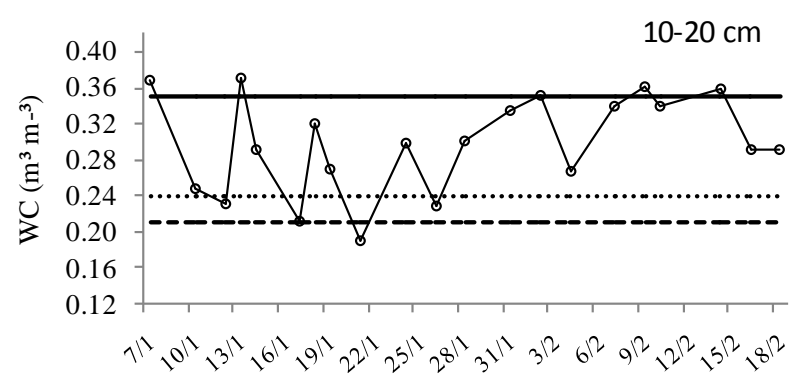

Date

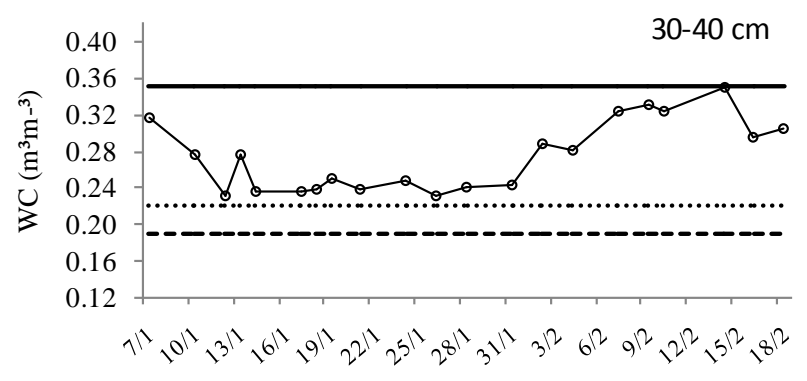

Date

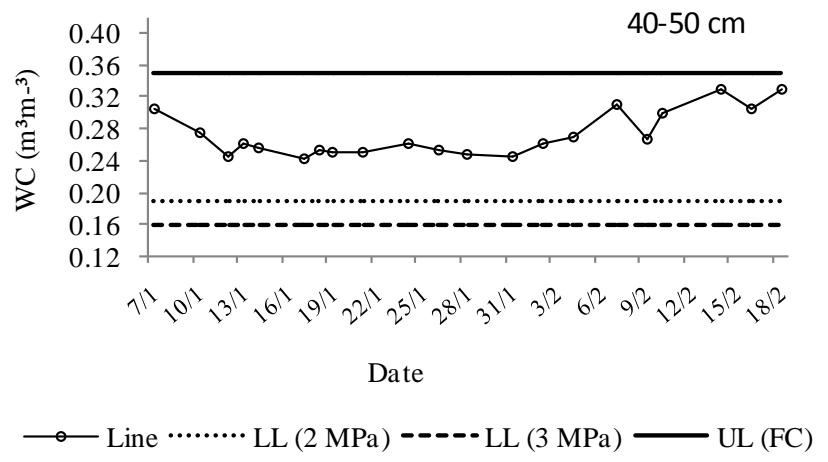

Figure 5 - Water content (WC; $\mathrm{m}^{3} \mathrm{~m}^{-3}$ ) of least limiting water range (LLWR) of the soil in the management with no-tillage chiseled (CNT) from January 7th, 2011 to February 18th, 2011 according to the sampled soil layer, being the upper limit (UL): water content to $6 \mathrm{kPa}$; lower limit (LL): resistance to penetration 2 or $3 \mathrm{MPa}$.

The difference between the managements (Table 3) highlights the importance of soil chiseling when compressed because, due to better infiltration and redistribution of water in the pores, besides the reduction in $\mathrm{RP}$ the soil moisture remained for more days within the LLWR, which culminates in proper development of plants and higher yields. Silva \& Kay (1996) demonstrated that the aerial growth rate and maize grain yield reduce the longer the moisture remains out of LLWR boundaries, corroborating the data obtained in this study.

For evaluation of biometric attributes of maize, 1,115 ears were collected, and the CNT had the best results (Table 3 ); the ear mass (rachis + grains) was $18.12 \mathrm{~g}$ higher than in NT, justified by the large number of grains per ear. The grain mass (13\% moisture) is also higher in CNT (17.32 g), which is one of the key components of the yield of maize grains (Lopes et al., 2007) and the increase in yield of grains is attributed to changes in cultural practices, genetic improvement, climate change and the interaction between these three factors (Tollenaar \& Wu, 1999). In this case, because it is the same hybrid and the rainfall is well distributed and homogeneous $(714 \mathrm{~mm}$, average $4.9 \mathrm{~mm} /$ day) in both managements, it reinforces the idea that the practice of chiseling in compacted soils is able to indirectly provide increase in yield of grains.

The number of grains per ear (extrapolation of the number of grains/row $x$ number of grain rows) was higher in the CNT (41 grains). On the other hand, rachis presented a mass difference of $1.49 \mathrm{~g}$ compared to NT. The number of rows per ear showed no difference, since this parameter is a characteristic of the hybrid cultivar, as well as the number of plants $\mathrm{m}^{-2}$ indicating, thus, an even seed distribution in the tillage managements. Custódio et al. (2003) state that the mass of the ear is influenced by the mode of cultivation, regardless of the maize tillage used. 
Table 4 - Biometric maize attributes: number of ears $/ \mathrm{m}^{2}$, number of grain rows per ear, number of grains per row, number of grains per ear, mass of grains, rachis, ear and of thousand grains, and yield of grains according to the management of no-tillage (NT) and chiseled no-tillage (CNT).

\begin{tabular}{lrrr}
\hline Biometric maize attributes & NT & CNT & CV (\%) \\
\hline Number of ears $/ \mathrm{m}^{2}$ & $5.81^{\mathrm{ns}}$ & 5.80 & 5.44 \\
Number of grain rows & $18.88 \mathrm{~ns}$ & 18.15 & 14.71 \\
Number of grains per row & $34.90 \mathrm{~B}$ & $36.69 \mathrm{~A}$ & 18.22 \\
Number of grains per ear & $632.58 \mathrm{~B}$ & $674.06 \mathrm{~A}$ & 21.12 \\
Mass of grains per ear & $197.31 \mathrm{~B}$ & $214.63 \mathrm{~A}$ & 24.05 \\
Mass of rachis $(\mathrm{g})$ & $17.30 \mathrm{~B}$ & $18.79 \mathrm{~A}$ & 4.15 \\
Mass of ear $(\mathrm{g})$ & $217.75 \mathrm{~B}$ & $235.87 \mathrm{~A}$ & 23.77 \\
Mass of thousand grains $(\mathrm{g})$ & $397.84 \mathrm{~B}$ & $405.74 \mathrm{~A}$ & 12.51 \\
Grain yield $\left(\right.$ Mg ha $^{-1}$ ) & $11.81 \mathrm{~B}$ & $12.42 \mathrm{~A}$ & 6.81 \\
\hline
\end{tabular}

${ }^{n}$ not significant; means followed by the same letter horizontally are not statistically different by the $t$ test at $5 \%$ probability.

The chiseling of compacted soils interferes positively on some production components and consequently on yield of grains, as the yield of maize grains was $0.609 \mathrm{Mg} \mathrm{ha}^{-1}$ higher in the CNT than in the NT. These results disagree with Pauletti et al (2003) who found no differences between the managements and Debiasi et al(2010) who observed reduction in the yield of maize grains when the soil was chiseled. These disagreements of results can be attributed to several factors, such as: state of soil compaction, time and efficiency of chiseling, plowing mechanisms and regulation of fertilizer seeder to operate in soils with different conditions, weather conditions and potential crop yield.

\section{Conclusions}

The least limiting water range was greater in the management of no-tillage chiseled.

In no-tillage cropping system the water content in the soil remains for a longer time out of the least limiting water range, both when considering the $\mathrm{RP}$ of $2 \mathrm{MPa}$ or of $3 \mathrm{MPa}$.

The maize crop had a higher yield of grains in the no-tillage chiseled cropping system.

\section{Acknowledgement}

To Coordination of Higher Education Personnel Training (Capes) for the granting the scholarship, and to Council National for Scientific and Technological Development (CNPq) for the productivity scholarship.

\section{References}

Aldrich SR, Scott WO, Leng ER (1982) Modern maize production. Champaign: A \& L Publication.371p.

Benjamin JG, Nielsen DC, Vigil MF (2003) Quantifying effects of soil conditions on plant growth and crop production. Geoderma 116 (1):137-148.

Busscher WJ (1990) Adjustment of flat-tipped penetrometer resistance data to common water content. Transactions American Society Agronomy and Engineering 33(2):519-524.

Camara RK, Klein VA (2005) Escarificação em plantio direto como técnica de conservação do solo e da água. Revista Brasileira de Ciência do Solo 29(5):789-796.
Custódio DP, Pasqualetto A, Oliveira IP (2003) Comportamento de cultivares de milho (Zea mays) e sistemas de cultivo. Revista Estudos 30(8):1793-1804.

Debiasi H, Levien R, Trein CR, Conte O, Kamimura KM (2010) Produtividade de soja e milho após coberturas de inverno e descompactação mecânica do solo. Pesquisa Agropecuária Brasileira 45 (6):603-612.

EMBRAPA - Empresa Brasileira de Pesquisa Agropecuária (1997), Manual de métodos de análise de solo, Centro Nacional de Pesquisa de Solos, 212p.

Gubiani PI, Reichert JM, Reinert DJ (2012) Indicadores hídrico-mecânicos de compactação do solo e crescimento de plantas. Revista Brasileira de Ciência do Solo 37(1):1-10.

Jawayardane NS, Chan KY (1994) The management of soil physical properties limiting crop producion in Australian sodic soils - A review. Australian Journal of Soil Science 32(1):13-44.

Kay BD, Silva AP, Baldock JA (1997) Sensivity of soil structure to changes in organic carbon content: predictions using pedotransfer functions. Canadian Journal of Soil Science 77(4):655-667.

Klein VA, Baseggio M, Madalosso T, Marcolin CD (2010) Textura do solo e a estimativa do teor de água no ponto de murcha permanente com psicrômetro. Ciência Rural, 40(7):1550-1556.

Klein VA, Camara RK (2007) Rendimento da soja e intervalo hídrico ótimo em Latossolo Vermelho sob plantio direto escarificado. Revista Brasileira de Ciência do Solo 31(2): 221-227.

Klein VA, Vieira ML, Durigon FF, Massing JP, Fávero F (2008) Porosidade de aeração de um Latossolo e rendimento de Trigo em plantio direto escarificado. Ciência Rural,38(2):1365-1371.

Lopes SJ, Storck ADLL, Damo HP, Brum B, Santos VJ (2007) Relações de causa e efeito em espigas de milho relacionadas aos tipos de híbridos. Ciência Rural, Santa Maria, 37(6):1536-1542. 
Modolo AJ, Fernandes HC, Schaeferm GCE, Silveira JCM (2008) Efeito da compactação do solo sobre a emergência de plântulas de soja em sistema de plantio direto, Ciência e Agrotecnologia, 32(4):1259-1265.

Nesmith DS (1987) Soil compaction in double cropped wheat and soybean an Ultisol. Soil Science Society of America Journal 51(1):183-186.

Pauletti V, Lima MR, Barcik C, Bittencourt A (2003) Rendimento de grãos de milho e soja em uma sucessão cultural de oito anos sob diferentes sistemas de manejo de solo e de culturas. Ciência Rural33 (3):491-495.

Secco D, Reinert DJ,Reichert JM, SILVA VR (2009) Atributos físicos e rendimento de grãos de trigo, soja e milho em dois Latossolos compactados e escarificados. Ciência Rural 39(1):58-64.

Silva AP, Kay BD (1996) The sensitivity of shoot growth of maize to the least limiting water range of soils. Plant and Soil 184(2):323-329.

Silva AP, Kay BD (1997) Effect of soil water content variation on the least limiting water range, Soil Science Society of American Journal.61(3):884-888.

Silva AP, Kay BD, Perfect E (1994) Characterization of the least limiting water range of soils. Soil Science Society of America Journal 58(6):1775-1781.

Silva AP, Kay BD, Perfect E (1997) Management versus inherent soil properties effects on bulk density and relative compaction. Soil and Tillage Research 44(1):81-93.

Silva Junior CA, Carvalho AA, Meurer I, Libardi PL, Silva MAC, Oliveira ECA (2010) Alterações nos atributos físicos de um Latossolo Vermelho sob diferentes métodos de preparo para o plantio da cana-de-açúcar. Agrarian 3(8):111-118.
Sojka RE (1992) Stomatal closure in oxygen-stressed plants Soil Science 154 (4):269-280.

Tavares Filho J, Barbosa GM, Guimarães MF, Fonseca ICB (2001) Resistência do solo à penetração e desenvolvimento do sistema radicular do milho (Zea mays) sob diferentes sistemas de manejo em um Latossolo Roxo. Revista Brasileira de Ciência do Solo 25(3):725-730.

Taylor HM, Gardner HR (1963) Penetration of cotton seedlings taproots as influenced by bulk density, moisture and strength of soil. Soil Science 96:153-156.

Taylor HM, Roberson GM, Parker JJ (1966) Soil strength root penetration relations for medium to coarse textured soil materials. Soil Science 102(1):18-22.

Tollenaar M, Wu J (1999) Yield improvement in temperate maize is attributable to greater stress tolerance. Crop Science 39(6):1597-1604.

Tormena CA, Silva AP, Gonçalves ACA, Folegatti MV (1999) Intervalo ótimo de potencial da água no solo: um conceito para avaliação da qualidade física do solo e manejo da água na agricultura irrigada. Revista Brasileira de Engenharia Agricola e Ambiental 3(3):286-292.

Veiga M, Horn R, Reinert DJ, Reichert JM (2007) Soil compressibility and penetrability of an Oxisol from southern Brazil, as affected by long-term tillage systems. Soil and Tillage Research 92(1):104-113.

Vieira ML, Klein VA (2007) Propriedades físicohídricas de um Latossolo Vermelho submetido a diferentes sistemas de manejo. Revista Brasileira de Ciência do Solo 31(6)1271-1280. 